\title{
Lublin Studies in
}

Modern Languages and Literature

VOL. 45

No 1 (2021) 


\title{
Lublin Studies in Modern Languages and Literature
}

\author{
Vielfalt des Gegenwartsdeutschen \\ The Diversity of Contemporary German
}

Gastherausgeber:

Christian Efing, Bruno Arich-Gerz, Isa-Lou Sander

UMCS

45(1) 2021

http://journals.umcs.pl//smll 


\title{
e-ISSN: $2450-4580$
}

\section{Publisher:}

Maria Curie-Skłodowska University Press

MCSU Library building, 3rd floor

ul. Idziego Radziszewskiego 11, 20-031 Lublin, Poland

phone: (081) 5375304

e-mail: sekretariat@wydawnictwo.umcs.lublin.pl

https://wydawnictwo.umcs.eu/

\section{Editorial Board}

\author{
Editor-in-Chief \\ Jolanta Knieja, Maria Curie-Skłodowska University, Lublin, Poland \\ Deputy Editors-in-Chief \\ Jarosław Krajka, Maria Curie-Skłodowska University, Lublin, Poland \\ Anna Maziarczyk, Maria Curie-Skłodowska University, Lublin, Poland \\ Statistical Editor \\ Tomasz Krajka, Lublin University of Technology, Poland \\ International Advisory Board
}

Anikó Ádám, Pázmány Péter Catholic University, Hungary

Monika Adamczyk-Garbowska, Maria Curie-Sklodowska University, Poland

Ruba Fahmi Bataineh, Yarmouk University, Jordan

Alejandro Curado, University of Extramadura, Spain

Saadiyah Darus, National University of Malaysia, Malaysia

Janusz Golec, Maria Curie-Sklodowska University, Poland

Margot Heinemann, Leipzig University, Germany

Christophe Ippolito, Georgia Institute of Technology, United States of America

Vita Kalnberzina, University of Riga, Latvia

Henryk Kardela, Maria Curie-Sklodowska University, Poland

Ferit Kilickaya, Mehmet Akif Ersoy University, Turkey

Laure Lévêque, University of Toulon, France

Heinz-Helmut Lüger, University of Koblenz-Landau, Germany

Peter Schnyder, University of Upper Alsace, France

Alain Vuillemin, Artois University, France 

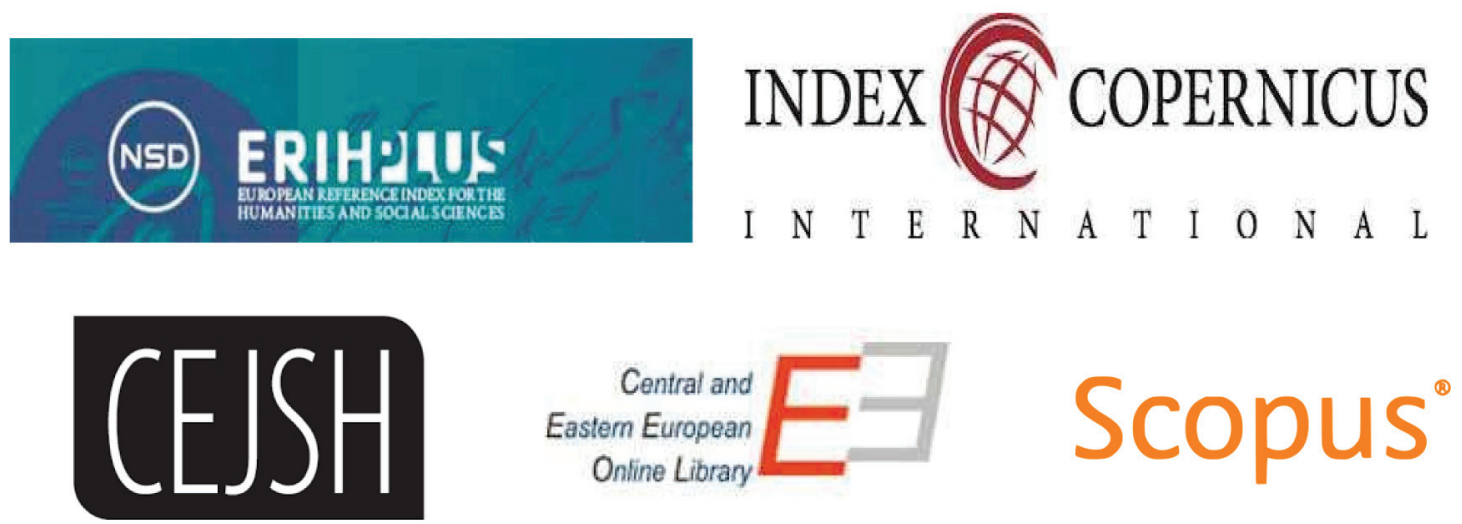

\section{Peer Review Process}

1. Each article is reviewed by two independent reviewers not affiliated to the place of work of the author of the article or the publisher.

2. For all publications, at least one reviewer's affiliation should be in a different country than the country of the author of the article.

3. Author/s of articles and reviewers do not know each other's identity (double-blind review process).

4. Review is in the written form and contains a clear judgment on whether the article is to be published or rejected.

5. Criteria for qualifying or rejecting publications and the reviewing form are published on the journal's website.

6. Identity of reviewers of particular articles or issues are not revealed, the list of collaborating reviewers is published once a year on the journal's website.

7. To make sure that journal publications meet highest editorial standards and to maintain quality of published research, the journal implements procedures preventing ghostwriting and guest authorship. For articles with multiple authorship, each author's contribution needs to be clearly defined, indicating the contributor of the idea, assumptions, methodology, data, etc , used while preparing the publication. The author submitting the manuscript is solely responsible for that. Any cases of academic dishonesty will be documented and transferred to the institution of the submitting author.

\section{Online Submissions - https://journals umes pl/lsmll}

Registration and login are required to submit items online and to check the status of current submissions. 


\section{Vielfalt des Gegenwartsdeutschen \\ The Diversity of Contemporary German}

\section{Inhaltsverzeichnis / Table of Contents}

Vielfalt des Gegenwartsdeutschen. Eine Einführung . . . . . . . . . 1

Christian Efing, Bruno Arich-Gerz, Isa-Lou Sander

Deutsch als Minderheitensprache $\ldots \ldots \ldots \ldots \ldots \ldots \ldots \ldots \ldots$

Claudia Maria Riehl, Rahel Beyer

Mehr als Dialekt-Relikte: Regionale Variation im Gegenwartsdeutschen . . 21 Robert Möller, Stephan Elspaß

Indexing Kiez - Zur Deethnisierung juventulektaler Stile . . . . . . 35

Nils Bahlo, Sharon Lohse

Fachsprachliche Vielfalt im Gegenwartsdeutschen ............. 51

Thorsten Roelcke

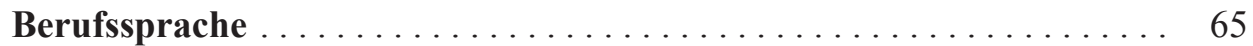

Isa-Lou Sander

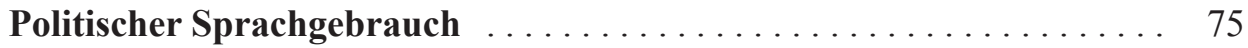

Thomas Niehr

Rollen der Internetnutzer im Online-Diskurs am Beispiel

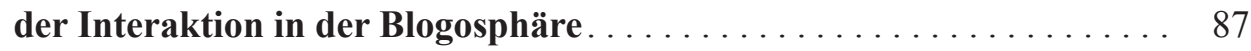

Joanna Pędzisz

Grammatische Entwicklungstendenzen der deutschen

Gegenwartssprache - ein Einblick . . . . . . . . . . . . . . . . . . 99

Christian Efing

Neologismen im Gegenwartsdeutschen - Probleme in Theorie

und Praxis

Hilke Elsen 